\title{
Historical changes in the benthos of the Wadden Sea around the island of Sylt in the North Sea*
}

\author{
Karsten Reise, Elisabeth Herre \& Manfred Sturm
}

Biologische Anstalt Helgoland, Wadden Sea Institute Sylt; D-2282 List, FRG

\begin{abstract}
The situation regarding the distribution and abundance of seagrass, macroalgae and benthic fauna near the island of Sylt in the south-eastern North Sea during the period 1923 to 1940 is compared with that of the 1980 s. Evidence of organic enrichment in recent times is provided by (1) massive growth of green algal mats on sheltered tidal flats, (2) a decline of red algae in the subtidal zone, (3) an expansion of mussel beds along low water line and down to $20 \mathrm{~m}$ depth, (4) increased abundance of polychaetes inhabiting intertidal and subtidal sandy bottoms. Seagrass beds have undergone complex changes which remain unexplained. Intensified erosion has contributed to the loss of habitats in the intertidal zone, and probably affected sessile epifauna in the deep channels. Here, direct removal and disturbance by the bottom-trawling fishery may also have contributed to the observed species impoverishment.
\end{abstract}

\section{INTRODUCTION}

Effective management of environmental quality requires some knowledge of the history of an ecosystem. Particularly a rational reconstruction of the effects of past human interferences may provide important lessons for future decisions. In this retrospective study, localities surveyed decades ago are reinvestigated. Past and present patterns in the benthos of the Wadden Sea are compared, and we ask to what extent have processes in the past generated the present ecological conditions.

Around the island of Sylt, the subtidal benthos with its oyster beds was qualitatively studied from 1869 to 1891 by Möbius $(1877,1893)$. Hagmeier \& Kändler (1927) and Hagmeier (1941) continued this survey from 1923 to 1940 , adding quantitative data. During this period, Nienburg $(1927)$ and Wohlenberg $(1935,1937)$ investigated the intertidal zone of Königshafen, a sheltered bay at the northern end of Sylt. Together, these studies provide a comprehensive picture of the benthos in this part of the Wadden Sea during the 1920 s and 1930s.

Recently, Riesen \& Reise (1982) and Reise \& Schubert (1987) revisited those subtidal sites which were quantitatively sampled by Hagmeier \& Kändler (1927). A qualitative long-term analysis was provided by Reise (1982). In this paper, we present reinvestigations of the intertidal zone. In addition, results from a recent dredge survey are compared with previous data to document long-term changes in the subtidal epibenthos of the North Frisian Wadden Sea.

\footnotetext{
* Presented at the VI International Wadden Sea Symposium (Biologische Anstalt Helgoland, Wattenmeerstation Sylt, D-2282 List, FRG, 1-4 November 1988)
} 


\section{AREA AND METHODS}

The intertidal survey is restricted to a sheltered, shallow bay called Königshafen, located between the village of List and the peninsula Ellenbogen at the northern end of the island of Sylt. The subtidal survey is concerned with the entire North Frisian Wadden Sea (Fig. 1). Sediments are relatively coarse grained in the north and fine grained in the south. Tidal range is $1.8 \mathrm{~m}$ in the north and $3.5 \mathrm{~m}$ in the south. Salinity remains close to $30 \%$. The average water temperature in summer is $15^{\circ} \mathrm{C}$, and every other winter some ice cover develops. Further descriptions of the area are given in Hagmeier \& Kändler (1927), Wohlenberg (1937) and Reise (1985).

In the subtidal zone, a simple, naturalist's dredge ( 6 and $1 \mathrm{~cm}$ meshes) was used in all surveys. The dredge had a wrought iron blade, $1 \mathrm{~m}$ in width at its lower edge. A net bag, $50 \mathrm{~cm}$ in length, was kept open by a rectangular frame. Samples were sorted on board. In the intertidal zone, sediment cores taken were washed through a 1-mm sieve and organisms were sorted in the laboratory when they were still alive. Distributional maps of conspicuous organisms were based on qualitative judgements in the early period (Nienburg, 1927; Wohlenberg, 1937) and on standardized recordings in the 1980s. A grid with quadrats $120 \mathrm{~m}$ in length was superimposed on Königshafen. Occurrence of mussel beds was mapped directly, while frequency estimates of other organisms were taken from 20 random point-observations within each quadrat. Maps are based on these data and are schematized to correspond as closely as possible to the early maps. In an area in the upper intertidal (Kerstens Rimling; Fig. 1) a grid with units of $30 \times 60 \mathrm{~m}$ was chosen with 1 point-observation per unit. This grid was adopted to detect any narrow belts in the distribution of the organisms.

\section{RESULTS}

\section{Königshafen}

S e a g r a s s. In 1924 seagrass covered a wide area. It showed a restricted distribution in 1934 and 1974, and was again fairly common in 1988 (Fig. 2). Wohlenberg (1935) reported a disease-related decline of Zostera marina L. in a subtidal bed east of Königshafen during 1933-34. This bed vanished entirely and never recovered. In $1974 Z$. noltii Hornem. occurred in small beds with distinct boundaries and $Z$. marina was a rare associate. Since $1979 Z$. noltii occurred more scattered and over a wider range in the tidal zone. At the same time $Z$. marina reappeared and gained dominance in 1988 .

Mussels and Fucus. Few beds of Mytilus edulis were present in the period 1924-34 compared to the 1980s (Fig. 3). After the severe winter 1962/63 new mussel beds spread along low tide line in eastern Königshafen (Ziegelmeier, 1977). These became partly destroyed by ice scouring in March 1969 and February 1979 but they always recovered quickly. Since 1986, these intertidal mussel beds have been subjected to heavy exploitation by the mussel fishery. Mussels are dredged from a ship during high tide and little, if any, clumps of mussels are left on the bare sediment.

In association with mussels, Fucus vesiculosus $\mathrm{L}$. occurs in a growth form without bladders. It is referred to as F. mytili by Nienburg (1927) and Wohlenberg (1937). Together with the mussel beds, this alga has become more abundant (Fig. 3).

Green algal mats. Nienburg (1927) described a bloom of Enteromorpha spp. in 


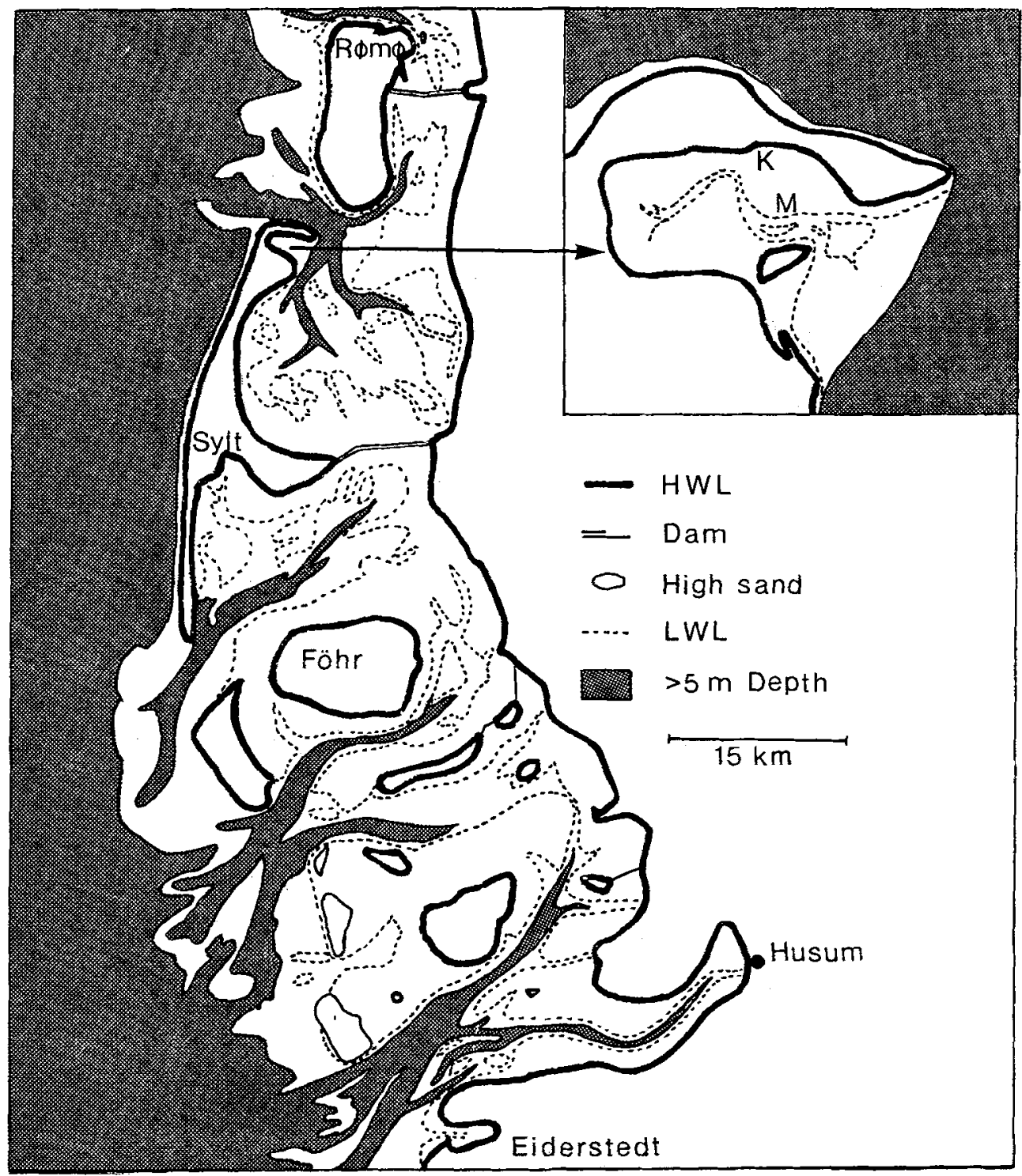

Fig. 1. North Frisian Wadden Sea in the south-eastern North Sea. Tidal flats (above dotted line = spring low tide level) and shallow subtidal zone $(<5 \mathrm{~m}$ depth) are given in white; deep channels ( $>5 \mathrm{~m}$ depth) and North Sea are shaded. Inset shows the intertidal bay of Königshafen at the northern end of Sylt. $\mathrm{K}=$ Kerstens Rimling, $\mathrm{M}=$ main tidal channel $\mathrm{HWL}$ and $\mathrm{LWL}=$ high and low water level, respectively

spring and early summer. This was restricted to the upper tidal zone and he indicated the sites on a map (Fig. 3). In August, these algae were no longer apparent. Garlands of Chaetomorpha linum (O. F. Müller) occurred in muddy depressions of south-eastern Königshafen. Kornmann (1952) sampled macroalgae in Königshafen from 1946 to 1951 , 
Seagrass beds in Königshafen

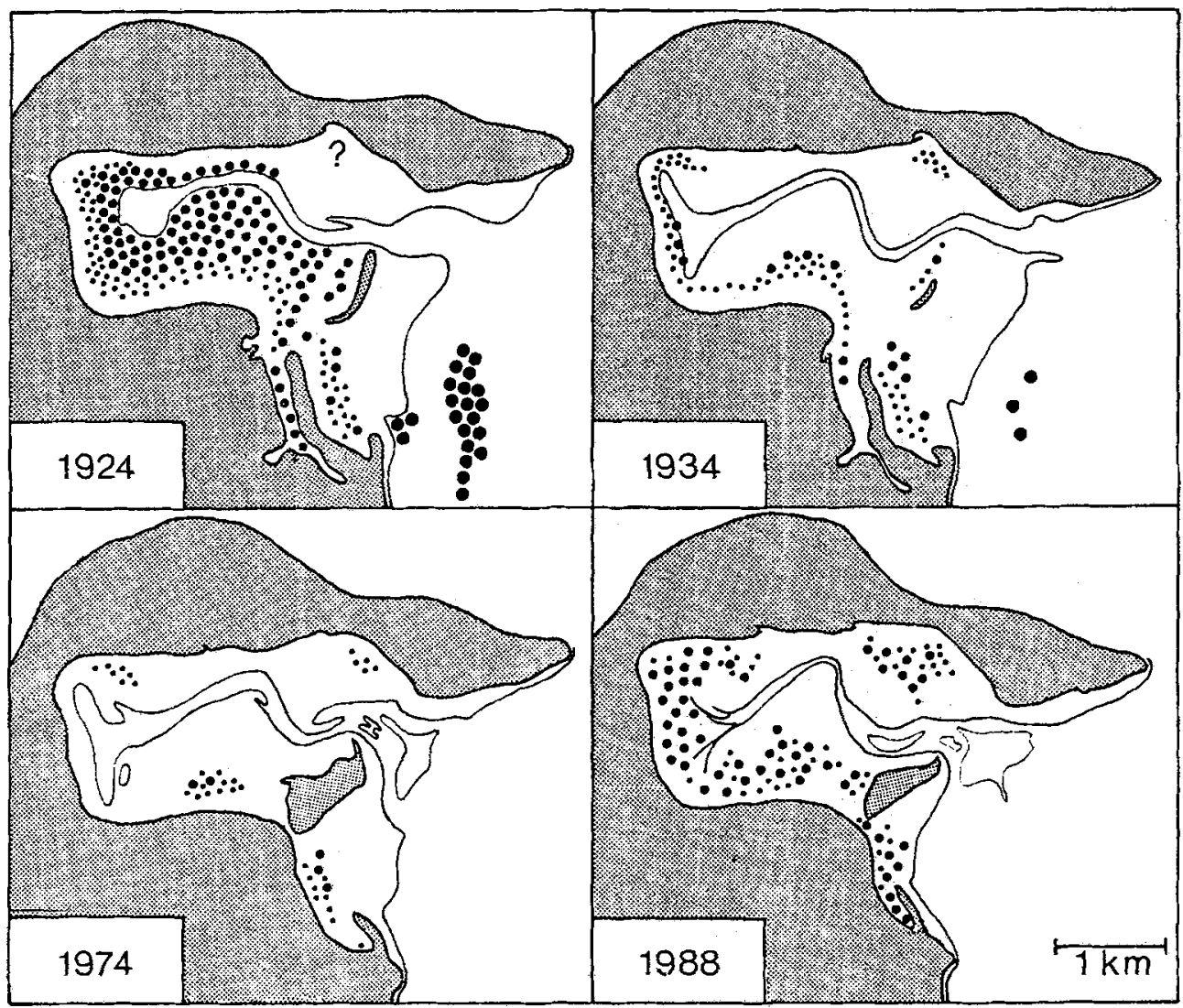

\section{large Zostera marina, $\therefore$ small Z.marina, $\therefore$ Z. noltii}

Fig. 2. Distribution of seagtasses in Königshafen. 1924: from map in Nienburg (1927); Zostera angustifolia and $Z$. stenophylla are here assumed to be small growth forms of $Z$. marina; 1934 : from partial maps and text notes in Wohlenberg $\{1935,1937\}$, complemented by interpretation of aerial photographs from August 1936; 1974 and 1988: own grid mapping and aerial photographs

noting Enteromorpha spp. in salt marsh ditches and a muddy lagoon, and also observing long garlands of $C$. linum.

With respect to green algae, the situation has changed dramatically since 1979 (Reise, 1983). Explosive growth of Enteromorpha spp. in June/July has led to the formation of thick algal mats. They are anchored in the sand and cover a wide range of the tidal zone until late August or September when storms remove them. Occasionally, Ulva lactuca L. attaches on top of these mats, and in 1988 Chaetomorpha sutoria (Berkeley) Kornm. covered two muddy lagoons. The map in Figure 3 (lower right) refers to September 1988.

Upper intertid a l. Wohlenberg (1937) described the morphogenesis, vegetation 


\section{4-34 Königshafen 1980s}

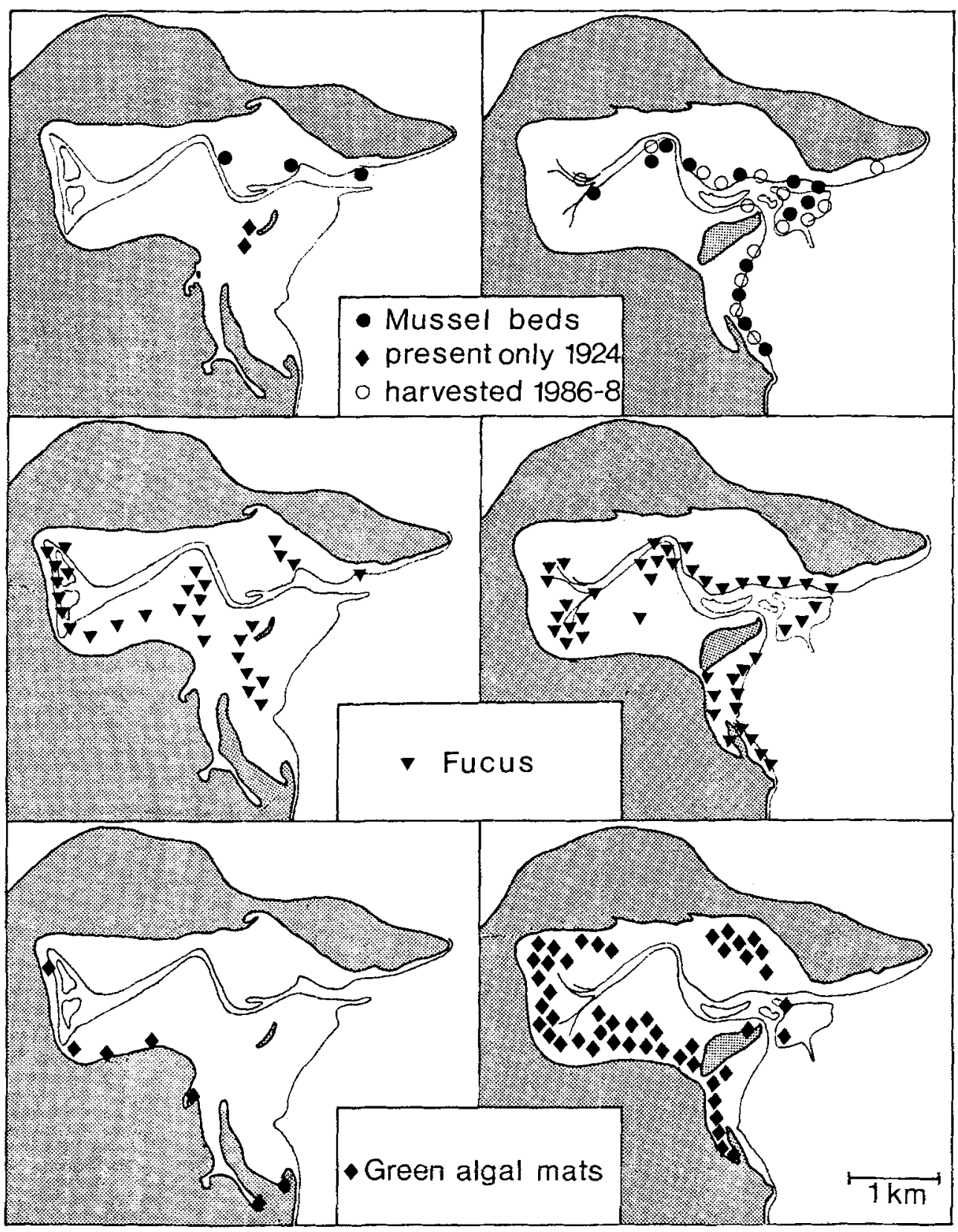

Fig. 3. Distribution of mussel beds, Fucus vesiculosus and green algal mats (spp. of Enteromorpha, Chaetomorpha and Ulva) in Königshafen. 1924 to 1934: from map in Nienburg (1927) and partial maps and text notes in Wohlenberg (1937); 1980s: own mapping and aerial photographs 
and macrofauna of a lagoon area called Kerstens Rimling ( $\mathrm{K}$ in Fig. 1). Coastal morphology was quite different 56 years later (Fig. 4). The sandy hook had fused with the shore line and probably become eroded to some extent.

The lower salt marsh with Puccinellia maritima (Huds.) Parl. in the western half of the lagoon in 1932 developed into an upper salt marsh with Ameria maritima (Mill.) Willd. and Festuca rubra L. The eastern part of the lagoon with Suaeda maritima (L.) Dum., Salicornia spp. and a few tussocks of $P$. maritima in 1932 was now a bare sandy area.

The cyanobacterial mats with burrows of the beetle Bledius spectabilis $\mathrm{Kr}$. inside and outside the lagoon were absent in 1988. The zoned pattern seaward from the lagoon in 1932 was completely mixed up in the 1980s. The belt of Corophium volutator (Pallas) completely vanished. Since 1975, this species has gradually declined in the entire Königshafen area and has remained present in only a few small patches. Juvenile (1-year old individuals) and adult lugworms were not separated any more into two belts, but intermingled in 1988. Seagrass was scattered over most of the area.

From these distributional changes it seems that the nearshore area became raised and more sandy over time, while the area seaward of the former lagoon deepened, allowing adult Arenicola marina L. and seagrass to occupy the entire zone. Habitats of the narrow-zoned assemblages between the upper salt marsh and the lugworm flat were apparently lost.

Lower intertidal. The bed of the main tidal channel in Königshafen has widened considerably since 1932 (Fig. 5). Much of the former lower tidal zone was permanently submerged in the 1980s. Clean sand areas populated by the polychaetes Scolelepis squamata and Ophelia rathkei became much smaller. A single mussel bed, present in 1932, was still found in the same position in 1988 but has since been largely destroyed by harvesting operations. There was some gravel underneath providing a suitable substrate for attachment. In 1988, further mussel beds were present along the entire northern shore of the channel.

Generally, the remaining lower tidal zone was more densely populated by infauna in 1988 than in 1932 (Fig. 5; Table 1). The low number of parallel samples ( 3 and 4 ) taken by Wohlenberg (1937) prevents a rigorous statistical evaluation. However, total abundances of samples taken in 1933 and in 1988 do not overlap. Thus error terms are less than 10 and $5 \%$ for the rejection of a null hypothesis for the clean sand and the lugworm flat, respectively (U-test of Wilcoxon, Mann and Whitney).

In the clean sand, total abundance increased 5.6-fold and species number increased from 8 to 13. In the lugworm flat, total abundance increased 4.3-fold and species number was 14 and 17. A similar quantitative comparison of macrofauna in a muddy lagoon in south-eastern Königshafen revealed no dramatic differences for most of the species. Another muddy area was completely covered by a green algal mat in 1988 . This was detrimental to the fauna underneath (see Reise, 1983).

\section{Epibenthos of the subtidal zone}

A lg a e. The composition and frequency of algae in dredge samples from the North Frisian Wadden Sea for the period 1932 to 1940 was recorded by Hagmeier (1941). He noted (for 1932) that most oyster beds had a rich stock of red algae, while brown and 


\section{Kerstens Rimling}

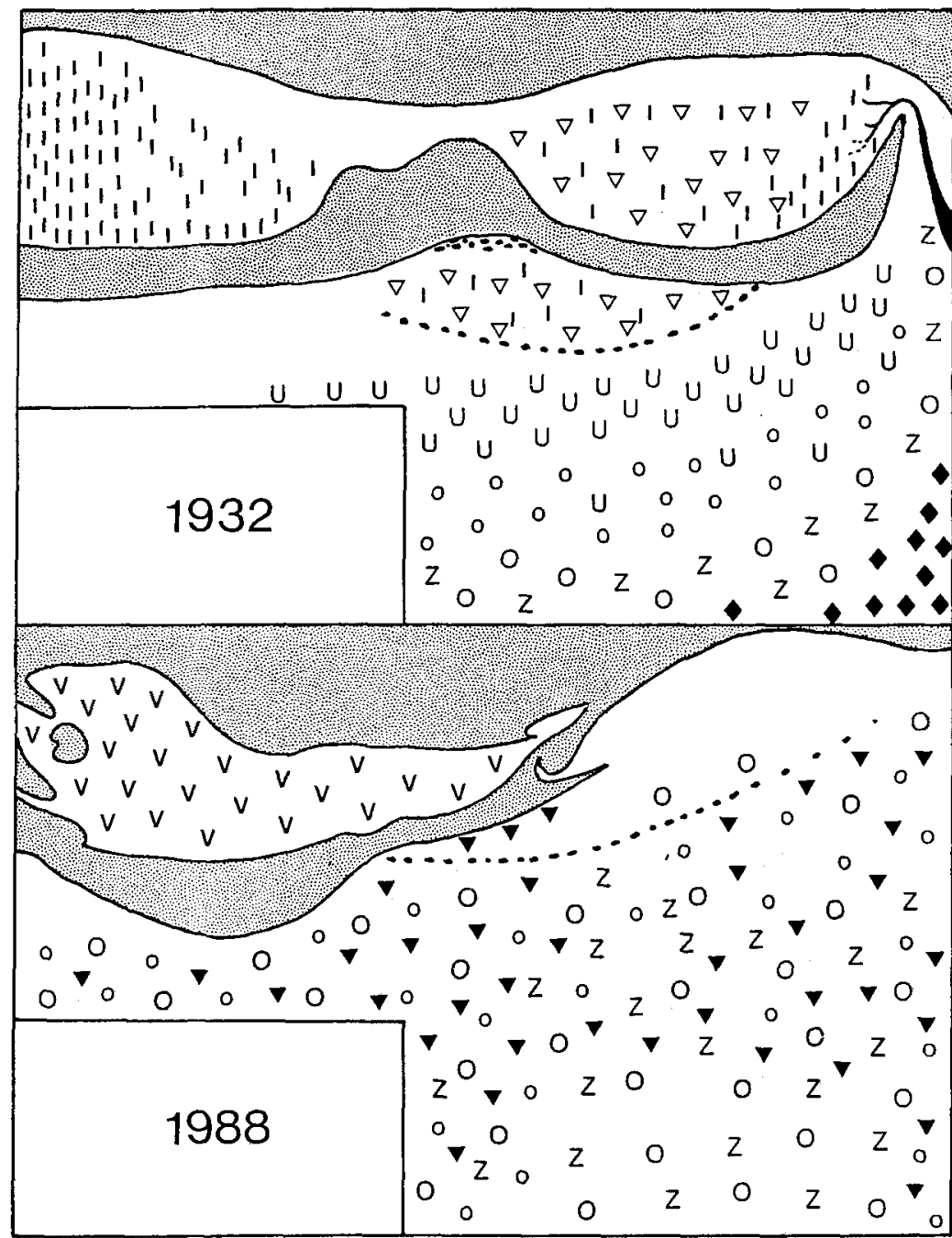

\footnotetext{
$v v$ High salt marsh

III Low salt marsh

$\nabla \nabla$ Bledius-zone

uU Corophium - zone
}

Sandy hook and dunes

-.. Pebbles

oo Arenicola, juv. +ad.

$\nabla \nabla$ Enteromorpha mats

\section{z z Zostera}

\section{- Mytilus + Fucus}

Fig. 4. Distribution of conspicuous organisms in a lagoon area on the southern shore of the peninsula Ellenbogen (Königshafen, Sylt). Size of area investigated approximately $600 \times 400 \mathrm{~m}$. 1932: simplified from Figure 21 in Wohlenberg (1937); 1988: comparable presentation derived from 130 point- 
Table 1. Abundance of macrofauna $(>1 \mathrm{~mm}$ ) in a clean sand area (arrow in Fig. 5) and in the surrounding lugworm flat in June 1933 (from Tables 20 and 21 in Wohlenberg [1937]) and August 1988. Each time $1500 \mathrm{~cm}^{2}$ (clean sand) and $2000 \mathrm{~cm}^{2}$ (lugworm flat) were sampled

\begin{tabular}{|lrr|}
\hline Clean sand: individuals $1500 \mathrm{~cm}^{-2}$ & 1933 & 1988 \\
\hline Diglotta mersa Halid. & 25 & 17 \\
Ophelia rathkei McIntosh & 28 & 227 \\
Scolelepis squamata (Müller) & 9 & 245 \\
Oligochaeta & 38 & 20 \\
Nereis diversicolor O. F. Müller & 0 & 21 \\
Pygospio elegans Clap. & 0 & 60 \\
Macoma balthica L. & 0 & 16 \\
others (7 species) & 14 & 30 \\
& & \\
\hline & & 1988 \\
Lugworm flat: individuals 2000 cm & 1933 & 8 \\
\hline Scolelepis squamata & & 56 \\
Pygospio elegans & 22 & 113 \\
Scoloplos armiger (O. F. Müller) & 14 & 46 \\
Nereis diversicolor & 25 & 77 \\
Capitella capitata (Fabr.) & 0 & 34 \\
Macoma balthica (juv.) & 1 & 22 \\
Hydrobia ulvae (Pennant) & 6 & 55 \\
others (13 species) & 0 & \\
& 27 & \\
\hline
\end{tabular}

green algae occurred more sporadically (Hagmeier, 1941, p. 149). By contrast, in dredge hauls of the 1980s red algae were rare and drifting brown and green algae were relatively frequent (Fig. 6). The difference in the relative frequencies of red algae is highly significant ( $\hat{z}=5.01$ after arcsin transformation of relative frequencies; Sachs 1983: 263). The depth range of Hagmeier's sites (mostly oyster beds) with red algae was 0.4 to $7.8 \mathrm{~m}$ below mean low tide level (given in Möbius, 1893). In the lower intertidal of Königshafen, red algae were common in the 1940s (Kornmann, 1952) and also in the 1980s (own data).

E p if a u n a. Most of the sessile epibenthos species that were frequently caught in the 1920s and 1930s were very rare or absent in the 1980s (Table 2). The only exceptions were mussels and the associated Metridium senile. Of the mobile predators and grazers, 3 were more frequent in former times, 4 show no significant differences, and Carcinus maenas is the only epibenthic species that was significantly more frequent in the 1980s.

\section{DISCUSSION}

A basic problem with studies in historical ecology results from the reliance on data which were gathered with different scientific aims in mind, and applying different methods and standards. Often, the earlier methods are insufficiently described to exclude any bias when they are repeated. In addition, the data in the old literature are rarely accessible to statistical treatment. All this requires a conservative attitude towards differences between early and recent data sets, and interpretations must be carried out with utmost caution. 
Main tidal channel of Königshafen

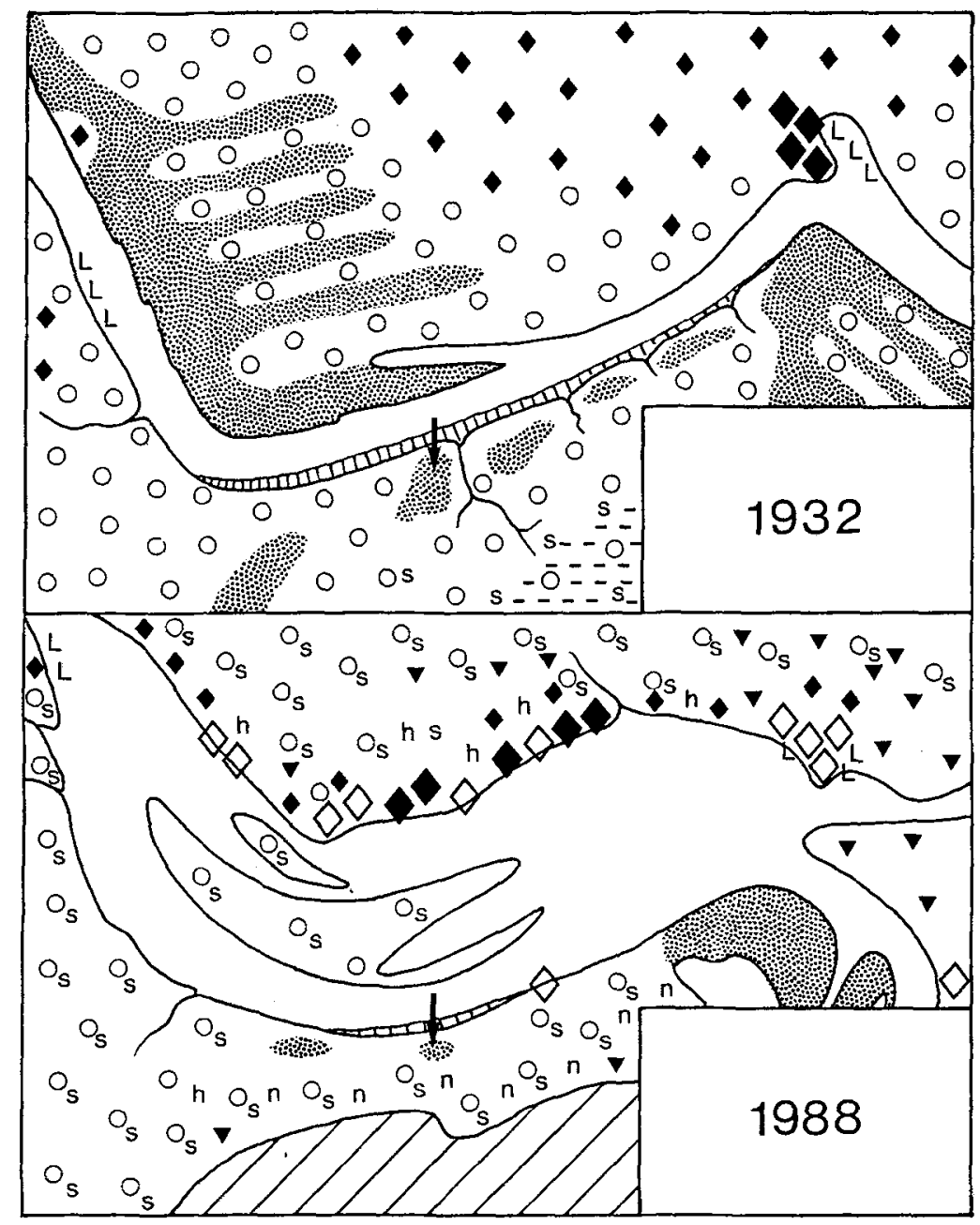

$\square$ Uthörn (man-made island) ता cliff out of clay

sand banks with Scolelepis $==$ seagrass bed

$\checkmark$ mussel bed $(\diamond$ harvested $)$

$\checkmark$ Enteromorpha mats

- clumps of mussels+Fucus

o Arenicola

L Lanice, s Scoloplos, h Heteromastus, $n$ Nereis

- low water line

Fig. 5. Distribution of conspicuous organisms on the flats around the main tidal channel of Königshafen. Size of area investigated: approximately $1150 \times 710 \mathrm{~m}$. 1932: redrawn from Figure 58 in Wohlenberg (1937); 1988: based on an aerial photograph from April 1984 and on 1140 pointobservations in August 1988 


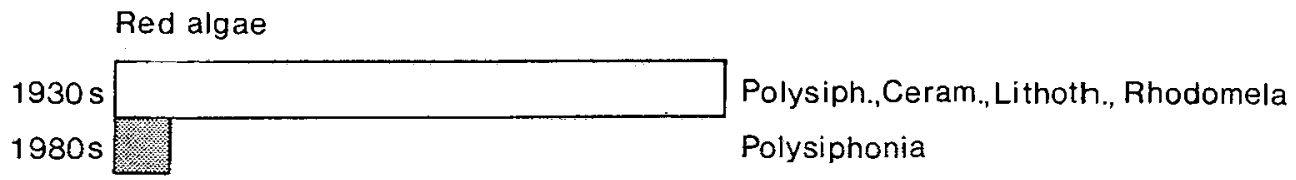

Brown algae

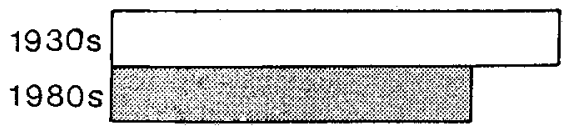

Fucus, Chorda, Dictyot a

Fucus, Laminaria

Green algae
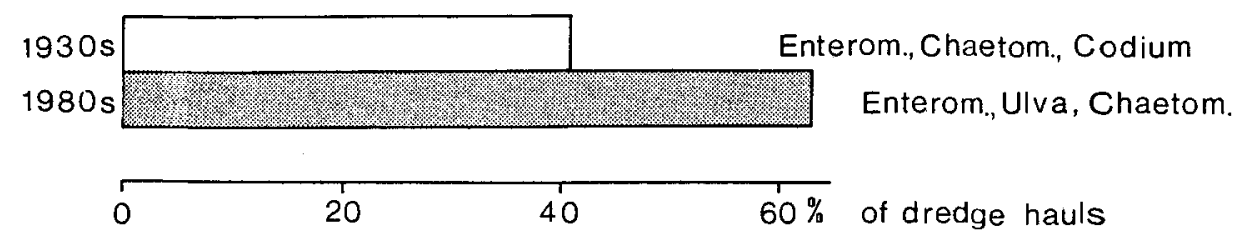

Fig. 6. Frequency (\%) of macroalgae in subtidal channels of the North Frisian Wadden Sea, dredged in 1932 to 1940 ( $n=27$ samples) and in 1987 to $1988(n=78$ samples) during summer months (June to August)

\section{Seagrass}

Changes observed in Königshafen partly correspond to changes observed elsewhere and thus deserve more than local interest. The dramatic decline of Zostera marina in the 1930 s occurred throughout the North Atlantic. The dominant interpretation is that of an epidemic disease (Short et al., 1988). In Königshafen, as in the Dutch Wadden Sea further south, subtidal beds never recovered (Hoek et al., 1979).

Apparently, Zostera noltii was not affected. However, in the 1970s it covered a smaller area than before. The same was observed in the Dutch Wadden Sea (Hartog \& Polderman, 1975) and in Jadebusen, an intertidal area $150 \mathrm{~km}$ south of Königshafen (Michaelis, 1987). Michaelis also observed a shift in dominance from $Z$. noltii to $Z$. marina.

The pattern of seagrass changes is complex and no conclusive interpretation can be offered. Some of the more recent declines in seagrass have been linked to pollution, i.e. to decreased transparency in the water column (Livingston, 1984; Ort \& Moore, 1984), and to massive epiphytal growth as a response to nutrient enrichment (Neverauskas, 1987; Silberstein et al., 1986). A coincidence of warm summers and mild winters with declines in Z. marina was pointed out by Rasmussen $(1973)$. Hartog $(1970,1985)$ suggested that frost, grazing, and self-induced sedimentation cause pluriannual cycles in intertidal seagrass beds. None of these suggestions alone offer a consistent explanation for the observed long-term changes in Königshafen. Continuous multifactorial studies seem to be necessary. 
Table 2. Frequency $(\%)$ of large epifauna $(>60 \mathrm{~mm})$ dredged in channels of the North Frisian Wadden Sea in 1924-40 ( $\mathrm{n}=46$ samples from Hagmeier \& Kändler [1927] and Hagmeier [1941]) and 1985-88 ( $n=98$ ) during summer. Species with <5\% frequency in both periods and ambiguous records (some encrusting spp. and hydroids) are excluded. $\mathrm{S}=$ sessile organism, $\mathrm{M}=$ mobile predator and/or grazer. Level of significance $(*=\mathrm{P}<0.05)$ is determined by arcsin transformed frequencies (Sachs, 1983: 263)

\begin{tabular}{|c|c|c|c|c|}
\hline \multicolumn{2}{|c|}{ Species } & \multirow{2}{*}{$\frac{1924-40}{85}$} & \multirow{2}{*}{$\frac{1985-88}{0}$} & \multirow{2}{*}{$\frac{\text { Significance }}{*}$} \\
\hline S & Ostrea edulis L. & & & \\
\hline $\mathrm{S}$ & Modiolus modiolus L. & 11 & 1 & \# \\
\hline $\mathrm{S}$ & Sabellaria spinulosa Leuck. & 30 & 0 & 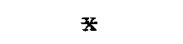 \\
\hline $\mathrm{S}$ & Pomatoceros triqueter $\mathrm{L}$. & 24 & 0 & 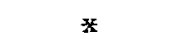 \\
\hline $\mathrm{S}$ & Alcyonidium gelatinosum (L.) & 28 & 0 & * \\
\hline $\mathrm{S}$ & Sagartiogeton undatus (Müll.) ${ }^{1}$ & 37 & 1 & * \\
\hline $\mathrm{S}$ & Urticina felina (L.) & 13 & 0 & * \\
\hline S & Alcyonium digitatum $\mathrm{L}$. & 7 & 0 & * \\
\hline $\mathrm{S}$ & Sertularia cupressina L. & 54 & 11 & \# \\
\hline$S$ & Cliona celata Grant & 11 & 0 & * \\
\hline S & Palichondria panicea (Pallas) & 39 & 8 & * \\
\hline M & Psammechinus miliaris (Gmelin) & 76 & 5 & 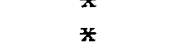 \\
\hline M & Asterias rubens L. & 98 & 73 & * \\
\hline M & Cancer pagurus. L. & 7 & 0 & * \\
\hline$S$ & Mytilus edulis $\mathrm{L}$. & 48 & 51 & * \\
\hline $\mathrm{S}$ & Metridium senile (L.) & 35 & 43 & \\
\hline M & Buccinum undatum $\mathrm{L}$. & 63 & 33 & \\
\hline $\mathrm{M}$ & Hyas araneus (L.) & 48 & 31 & \\
\hline M & Liocarcinus holsatus (Fabr.) & 48 & 50 & \\
\hline M & Pagurus bernhardus L. & 85 & 96 & \\
\hline $\mathrm{M}$ & Carcinus maenas (L.) & 61 & 94 & * \\
\hline
\end{tabular}

\section{Algae}

Two opposing trends occurred in the study area: green algae exhibited massive growth and brown algae showed a moderate increase, while on the other hand red algae became rare in the subtidal zone. Both trends may be explained with coastal eutrophication. Extensive green algal mats in the vicinity of sewage outlets have been reported from several shores since the 1970s (i.e. Perkins \& Abbott, 1972; Wharfe, 1977; Nicholls et al., 1981), and it was described for Königshafen by Reise (1983).

In contrast to algal development in the intertidal zone, red algae diminished in the subtidal. Since red algae remained common in the lower intertidal zone, a reduction in transparency provides a plausible explanation. Increased turbidity might have been caused by dams or by an increased primary production in the water column of the Wadden Sea (Cadée \& Hegeman, 1979; Cadée, 1986). Diminished vertical distribution of macroalgae compared to earlier records is also known from the Baltic Sea (Kautsky et al., 1986) and the Skagerrak (Svane \& Gröndahl, 1988), and decreased transparency was suggested as a possible cause. 


\section{Mussel beds}

Similar to seagrass meadows, beds of Mytilus edulis are ecologically elite structures in the Wadden Sea in terms of biomass production, nutrient cycling, and habitat provision to a rich assemblage of associated organisms (Asmus, 1987; Dame \& Dankers, 1988). Changes in the distribution and coverage of mussel beds could have large effects on the entire ecosystem.

Comparing the 1920s with the 1980s, Riesen \& Reise (1982) and Reise \& Schubert (1987) showed an increase of mussel beds in the subtidal zone down to a depth of $20 \mathrm{~m}$. This study adds an increase for the intertidal zone. In former times mussel beds occurred mainly around low tide line but repeatedly invaded oyster beds living in the upper subtidal zone (Hagmeier \& Kändler, 1927). Further south in the Wadden Sea, in the lower intertidal of Jadebusen, Michaelis (1987) found a 2.5-fold increase in coverage of mussel beds from the 1930s to the 1970s. Long-term comparisons from the Baltic Sea also document a recent increase in mussel abundance (Brey, 1986; Cederwall \& Elmgren, 1980). An increase in phytoplankton over the last decades is known from the western Wadden Sea (Cadée, 1986) and Helgoland Bight (Radach \& Berg, 1986). Mussels may have benefitted from this improved food supply.

In the North Frisian Wadden Sea, commercial mussel fishery proliferated strongly during the 1980s. Natural beds were harvested, and those of the intertidal zone provided much of the 'seed mussels' for new mussel cultures set up at the bottom of the subtidal zone. The high abundance of mussels recorded by Riesen \& Reise (1982) and Reise \& Schubert (1987) was no longer apparent in dredge hauls taken during the second half of the 1980s (Table 2). Natural beds are presently severely exploited, both in the intertidal and in the subtidal zone.

\section{Infaunal enrichment}

Particularly infaunal polychaetes were more abundant in the 1980s than in the 1920s in the subtidal zone north (Riesen \& Reise, 1982) and south (Reise \& Schubert, 1987) of Sylt. The same trend is obvious when intertidal sand flats are compared between the 1930 s and the 1980s (this paper). The increase includes large-sized, mature individuals (i.e. Scoloplos, Nereis, Scolelepis) and thus is unlikely to be an artifact of improved sieving or sorting methods in the present study. No such increase was observed in a muddy lagoon. This suggests organic enrichment of the sandy areas causing higher polychaete abundance.

Similarly, continuous sampling of macrofauna in the intertidal zone of the Western Wadden Sea since 1970 has revealed increasing trends for several infaunal species, suggesting a response to eutrophication (Beukema \& Cadée, 1986; Beukema \& Essink, 1986).

\section{Sea level rise and erosion}

The distinctly zoned pattern of biota in the upper tidal zone of Königshafen in the 1930 s was absent in the $1980 \mathrm{~s}$. Much of the lower tidal zone close to the major tidal channel of the 1930s was permanently submerged in the 1980s. Both phenomena suggest erosive processes operating in Königshafen. In this area, tidal range increased by $0.20 \mathrm{~m}$ 
and mean high water by $0.14 \mathrm{~m}$ since 1931 (from Führböter \& Jensen; 1985). This may have triggered erosion on the tidal flats. In areas with progressive coastal protection, biotic assemblages of the upper tidal zone might run out of habitat if sea level continues to rise. However, local deviations from such a trend are to be expected. For example, on tidal flats in the bay of Jadebusen, sedimentation outweighs sea level rise (Frels \& Demuth, 1987).

\section{Epifaunal losses}

Two habitat generating species, oysters and reefs of Sabellaria spinulosa, were exploited or destroyed directly by the fishery (Reise, 1980, 1982). Until the 1950s, hydroid colonies were dredged for decorative purposes (local sources). These impacts certainly affected associated species but are unlikely to account for all the losses in the sessile epibenthos.

If there are any general causes for the observed changes, these must explain the differential trends in sessile and mobile species. Two non-exclusive hypotheses should be considered: (1) Bottom stability has decreased over the years and has rendered survival of sessile individuals and colonies more difficult. An increasing erosion is well documented for the tidal basins of the North Frisian Wadden Sea (Taubert, 1986). However, any detailed observations on how erosion affects sessile forms on secondary hard bottoms are lacking up to now. (2) The present bottom trawling fishery causes more disturbances in the benthos than it did decades ago. Total landings of the shrimp fishery have fluctuated but have not increased since the 1920s (Tiews, 1983). Fishing gear has become larger and more efficient but the size of the fleet has declined. Thus, there is no evidence for increasing deleterious effects on the sessile epibenthos caused by the fishery, although a cumulative effect cannot be ruled out. Comparisons of fished and unfished areas would be enlightening. However, the latter do not exist in the studied region.

\section{CONCLUSIONS}

Nutrient concentrations in the North Frisian Wadden Sea are considerably lower than further south along the German coast (Martens, 1989). Nevertheless, several of the long-term changes observed in the Wadden Sea around the island of Sylt are consistent with the assumption that increased nutrient concentrations in the coastal waters have caused an enrichment effect: (1) massive growth of green algal mats in sheltered intertidal zones, (2) loss of red algae from the deeper bottoms, (3) expansion of mussel beds in the intertidal zone and over the entire depth range of the subtidal zone, (4) increased abundance of infaunal species in the sandy bottoms of the intertidal and subtidal zone (Fig. 7).

Positive responses by the benthos to enhanced eutrophication have also been observed in other regions of the Wadden Sea (Beukema \& Cadée, 1986; Madsen \& Jensen, 1987; Michaelis, 1978, 1987). Deleterious effects, on the other hand, are known from sites close to effluents of organic wastes. This is attributed to hypoxia (Essink, 1984; Essink \& Beukema, 1986). Similarly, Rosenberg et al. (1987) found increased macrobenthic biomass in Oslofjord, and interpreted this as a response to nutrient enrichment. In the adjacent Kattegat and in 3 West Swedish fjords, Pearson et al. (1985) and Josefson \& Rosenberg (1988) observed biomass reductions, and suggested hypoxia as a consequence 


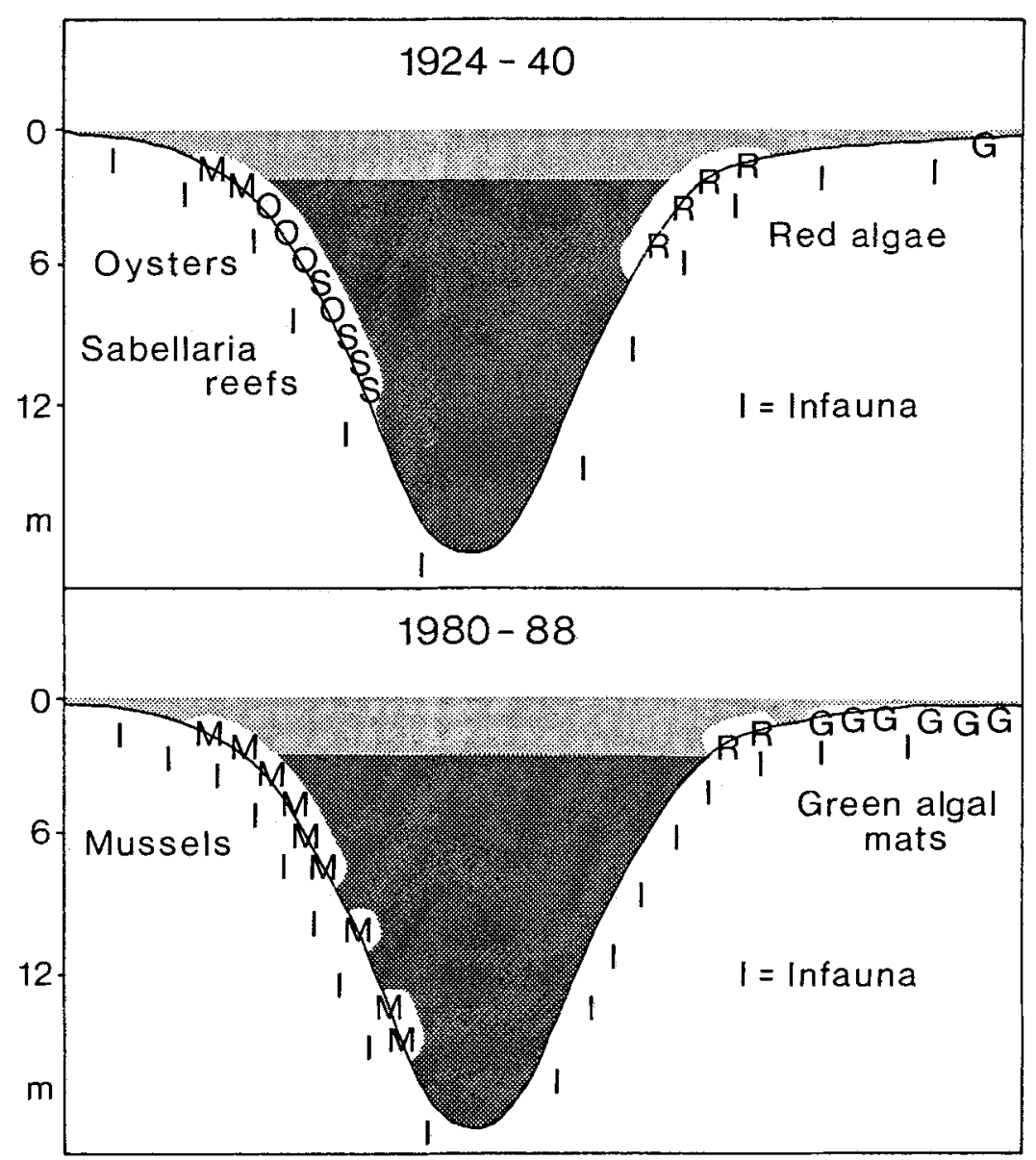

Fig. 7. Schematic summary of benthic long-term changes along the slopes of a deep tidal channel (dark $=$ subtidal) and on the adjacent tidal flats (light grey) of the Wadden Sea around Sylt

of excess nutrients to be the cause. In the Baltic Sea, Cederwall \& Elmgren (1980) and Brey (1986) found increased biomass above the halocline, while below the halocline macrobenthos was adversely affected (Weigelt \& Rumohr, 1986). Again, direct and indirect effects of eutrophication were invoked.

In the North Frisian Wadden Sea, the prevailing physical conditions with strong tidal currents and rolling waves normally prevent hypoxia. In the vicinity of mussel beds, however, resuspended biodeposits may cause oxygen deficiencies in the near bottom water (Asmus et al., unpubl.). Unfortunately, in the deep tidal channels where the sessile epifauna has declined, oxygen concentrations have not been measured up to now. Still, precaution necessitates the reduction of nitrogen and phosphorous release into the Wadden Sea, in order to prevent such oxygen depletions as were measured in the adjacent North Sea (Rachor \& Albrecht, 1983; Westernhagen et al., 1986).

Not all of the observed long-term changes in the benthos around Sylt can be 
attributed to enhanced eutrophication. Erosion contributed to the loss of narrow-zoned assemblies in the upper intertidal, and possibly also to losses in the epifauna of the deep channels. Fishery almost certainly affected oysters, mussels and Sabellaria-reefs. The presented historical comparisons cannot be conclusive with regard to the causes. However, they document that considerable long-term changes have actually occurred. This fact alone deserves our continuing attention, in science as well as in nature management.

Acknowledgements. We thank the crew of the RV "Mya", N. Kruse and P. Elvert, for 98 dredge hauls. R. Berghahn, H. Michaelis and R. Rosenberg provided valuable criticisms on the manuscript.

\section{LITERATURE CITED}

Asmus, H., 1987. Secondary production of an intertidal mussel bed community related to its storage and turnover compartments. - Mar. Ecol. Prog. Ser. 39, 251-266.

Beukema, J. J. \& Cadée, G. C., 1986. Zoobenthos responses to eutrophication of the Dutch Wadden Sea. - Ophelia 26, 55-64.

Beukema, J. J. \& Essink, K., 1986. Common patterns in the fluctuations of macrozoobenthic species living at different places on tidal flats in the Wadden Sea. - Hydrobiologia. 142, 199-207.

Brey, T., 1986. Increase in macrozoobenthos above the halocline in Kiel Bay comparing the 1960s with the 1980s. - Mar. Ecol. Prog. Ser. 28, 299-302.

Cadée, G. C., 1986. Increased phytoplankton primary production in the Marsdiep area (Western Dutch Wadden Sea). - Neth. J. Sea Res. 20, 285-290.

Cadée, G. C. \& Hegeman, J., 1979. Phytoplankton primary production, chlorophyll and composition in an inlet of the Western Wadden Sea (Marsdiep). - Neth. J. Sea Res. 13, 224-241.

Cederwall, H. \& Elmgren, R., 1980. Biomass increase of benthic macrofauna demonstrates eutrophication of the Baltic Sea. - Ophelia (Suppl.) 1, 287-304.

Dame, R. F. \& Dankers, N., 1988. Uptake and release of materials by a Wadden Sea mussel bed. - J. exp. mar. Biol. Ecol. 118, 207-216.

Essink, K., 1984. The discharge of organic waste into the Wadden Sea: local effects. - Publ. Ser. Neth. Inst. Sea Res. 10, 165-178.

Essink, K. \& Beukema, J. J., 1986. Long-term changes in intertidal flat macrozoobenthos as an indicator of stress by organic pollution. - Hydrobiologia. 142, 209-215.

Frels, G. \& Demuth, A., 1987. Der Jadebusen und seine Watten: Verlandung des Jadebusens oder nur Ausgleich des Meeresspiegelanstieges? - Küste 45, 117-121.

Führböter, A. \& Jensen, J., 1985. Säkularänderungen der mittleren Tidewasserstände in der Deutschen Bucht. - Küste 42, 78-100.

Hagmeier, A., 1941. Die intensive Nutzung des nordfriesischen Wattenmeeres durch Austern- und Muschelkultur. - Z. Fisch. 39, 105-165.

Hagmeier, A. \& Kändler, R., 1927. Neue Untersuchungen im nordfriesischen Wattenmeer und auf den fiskalischen Austernbänken. - Wiss. Meeresunters. (Abt. Helgoland) 16, 1-90,

Hartog, C. den, 1970. The seagrasses of the world. - Verh. K. ned. Akad. Wet. (Afd. Natuurk. 2. R.) $59,1-275$.

Hartog, C. den, 1985. Factors effecting seagrass bed formation and breakdown (abstract). - Estuaries $8,15 \mathrm{~A}$.

Hartog, C. den \& Polderman, P. J. G., 1975. Changes in the seagrass populations of the Dutch Wadden Sea. - Aquat. Bot. 1, 141-147.

Hoek, C. van den, Admiraal, W., Colijn, F. \& De Jonge, V. N., 1979. The role of algae and seagrasses in the ecosystem of the Wadden Sea: A review. In: Flora and vegetation of the Wadden Sea. Ed. by W. J. Wolff. Balkema, Rotterdam, 9-118. (Rep. Wadden Sea Working Group. 3.)

Josefson, A. B. \& Rosenberg, R., 1988. Long-term soft-bottom faunal changes in three shallow fjords, West Sweden. - Neth. J. Sea Res. 22, 149-159.

Kautsky, N., Kautsky, H., Kautsky, U. \& Waern, M., 1986. Decreased depth penetration of Fucus vesiculosus (L.) since the 1940s indicates eutrophication of the Baltic Sea. - Mar. Ecol. Prog. Ser. $28,1-8$. 
Kornmann, P., 1952. Die Algenvegetation von List auf Sylt. - Helgoländer wiss. Meeresunters. 4, $55-61$.

Livingston, R. J., 1984. Trophic response of fishes to habitat variability in coastal seagrass systems. Ecology 65, 1258-1275.

Madsen, P. B. \& Jensen, K., 1987. Population dynamics of Macoma balthica in the Danish Wadden Sea in an organically enriched area. - Ophelia $27,197-208$.

Martens, P., 1989. Inorganic phytoplankton nutrients in the Wadden Sea areas off SchleswigHolstein. I. Dissolved inorganic nitrogen. - Helgoländer Meeresunters. 43, 77-85.

Möbius, K., 1877. Die Auster und die Austernwirthschaft. Wiegandt, Hempel \& Parey, Berlin, $126 \mathrm{pp}$.

Möbius, K., 1893. Über die Tiere der schleswig-holsteinischen Austernbänke, ihre physikalischen und biologischen Lebensverhältnisse. - Sber. preuss. Akad. Wiss. 7, 33-58.

Michaelis, H., 1978. Recent biological phenomena in the German Waddensea. - Rapp. P.-v. Réun. Cons. int. Explor. Mer 172, 276-277.

Michaelis, H., 1987. Bestandsaufnahme des eulitoralen Makrobenthos im Jadebusen in Verbindung mit einer Luftbild-Analyse. - Jber. ForschSt. Küste, Norderney 38, 1-97.

Neverauskas, V. P., 1987. Monitoring seagrass beds around a sewage sludge outfall in South Australia. - Mar. Pollut. Bull. 18, 158-164.

Nicholls, D. J., Tubbs, C. R. \& Haynes, F. N., 1981. The effect of green algal mats on intertidal macrobenthic communities and their predators. - Kieler Meeresforsch. (Sonderh.) 5, 511-520.

Nienburg, W., 1927. Zur Ökologie der Flora des Wattenmeeres. I. Teil. Der Königshafen bei List auf Sylt. - Wiss. Meeresunters. (Abt. Kiel) 20, 146-196.

Orth, R. J. \& Moore, K. A., 1984. Distribution and abundance of submerged aquatic vegetation in Chesapeake Bay: an historical perspective. - Estuaries 7, 531-540.

Pearson, T. H., Josefson, A. B. \& Rosenberg, R., 1985. Petersen's stations revisited. I. Is the Kattegat becoming eutrophic? - J. exp. mar. Biol. Ecol. 92, 157-206.

Perkins, E. J. \& Abbott, O. J., 1972. Nutrient enrichment and sand flat fauna. - Mar. Pollut. Bull. 3, 70-72.

Rachor, E. \& Albrecht, H., 1983. Sauerstoff-Mangel im Bodenwasser der Deutschen Bucht. - Veröff. Inst. Meeresforsch. Bremerhaven 19, 209-227.

Radach, G. \& Berg, J., 1986. Trends in den Konzentrationen der Nährstoffe und des Phytoplanktons in der Helgoländer Bucht (Helgoland Reede Daten). - Ber. Biol. Anst. Helgoland 2, 1-63.

Rasmussen, E., 1973. Systematics and ecology of the Isefjord marine fauna (Denmark). - Ophelia 11, $1-495$.

Reise, K., 1980. Hundert Jahre Biozönose. - Naturw. Rdsch., Stuttg. 33, 328-335.

Reise, K., 1982. Long-term changes in the macrobenthic invertebrate fauna of the Wadden Sea: are polychaetes about to take over? - Neth. J. Sea Res. 16, 29-36.

Reise, K., 1983. Sewage, green algal mats anchored by lugworms, and the effects on Turbellaria and small Polychaeta. - Helgoländer Meeresunters. 36, 151-162.

Reise, K., 1985. Tidal flat ecology. Springer, Berlin, $191 \mathrm{pp}$.

Reise, K. \& Schubert, A., 1987. Macrobenthic turnover in the subtidal Wadden Sea: the Norderaue revisited after 60 years. - Helgoländer Meeresunters. 41, 69-82.

Riesen, W. \& Reise, K., 1982. Macrobenthos of the subtidal Wadden Sea: revisited after 55 years. Helgoländer Meeresunters. 35, 409-423.

Rosenberg, R., Gray, J. S., Josefson, A. B. \& Pearson, T. H., 1987. Petersen's benthic stations revisited. II. Is the Oslofjord and eastern Skagerrak enriched? - J. exp. mar. Biol. Ecol. 105, 219-251.

Sachs, L., 1983. Angewandte Statistik. Springer, Berlin, 552 pp.

Short, F. T., Ibelings, B. W. \& Hartog, den C., 1988. Comparison of a current eelgrass disease to the wasting disease in the 1930s. - Aquat. Bot. 30, 295-304.

Silberstein, K., Chiffings, A. W. \& Comb, A. J., 1986. The loss of seagrass in Cockburn Sound, Western Australia. III. The effect of epiphytes on productivity of Posidonia australis Hook F. Aquat. Bot. 24, 355-371.

Svane, I. \& Gröndahl, J., 1988. Epibioses of Gullmarsfjorden: an underwater stereophotographical transect analysis in comparison with the investigations of Gislén in 1926-29. - Ophelia 28, $95-110$. 
Taubert, A., 1986. Morphodynamik und Morphogenese des Nordfriesischen Wattenmeeres. Hamburger geogr. Stud. 42, 1-263.

Tiews, K., 1983. Über die Veränderungen im Auftreten von Fischen und Krebsen im Beifang der deutschen Garnelenfischerei während der Jahre 1954-1981. - Arch. FischWiss. 34, 1-156.

Weigelt, M. \& Rumohr, H., 1986. Effects of wide-range oxygen depletion on benthic fauna and demersal fish in Kiel Bay 1981-1983. - Meeresforsch. 31, 124-136.

Wharfe, J. J., 1977. An ecological survey of the benthic invertebrate macrofauna of the lower Medway estuary, Kent. - J. Anim. Ecol. 46, 93-110.

Westernhagen, H. v., Hickel, W., Bauerfeind, E., Niermann, U. \& Kröncke, I., 1986. Sources and effects of oxygen deficiencies in the southeastern North Sea. - Ophelia 26, 457-473.

Wohlenberg, E., 1935. Beobachtungen über das Seegras, Zostera marina, und seine Erkrankung im nordfriesischen Wattenmeer. - Nordelbingen 11, 1-19.

Wohlenberg, E., 1937. Die Wattenmeer-Lebensgemeinschaften im Königshafen von Sylt. - Helgoländer wiss. Meeresunters. 1, 1-92.

Ziegelmeier, E., 1977. Ein Naturexperiment im Watt. Beobachtungen an einer Miesmuschelbank. Natur Mus., Frankf. 107, 239-243. 